\title{
Bacterial Shock
}

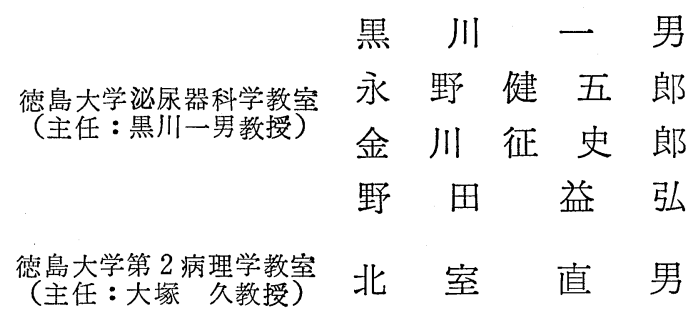

\section{BACTERIAL SHOCK}

Kazuo Kurokawa, Kengoro Nagano, Seishiro Kanagawa and Masuhiro Noda

The Department of Urology, School of Medicine, Tokushima University

(Director: Prof. Kazuo Kurokawa)

Tadao Kitamuro

The Department of 2nd Pathology, School of Medicine, Tokushima University

(Director: Prof. Hisashi Otsuka)

Two cases of bacterial shock were observed in one patient, 77-year-old with prostatic hypertrophy while a catheter was implanted and the other patient, 72-year-old with a bladder stone after a bladder irrigation with caliculi solvent. The patients were cured of the shock with antibiotics, vaso pressor drug, cardiac stimulants were steroid hormones.

The causes and therapies are discussed.

はじめに

Brill \& Libman は1889年に血性下痢, 呕吐を主症 状としたグラム陰性菌血症の症例を報告した。続いて Jacob (1909), Felty \& Keefer（1924）は高熱と白血球 増多症を示摘し，Weisbren（1951）に至り初めて菌血 症によるショックの概念が確立された。 Weisbren は “Shock like picture”なる用語を用いてその基本的な 症状を低血圧，低体温，低皮膚温，昏睡であると述へ， 29例について報告している.

Weisbren の報合に続き幾多の Bacterial Shock の臨 床例が 発表されると共に動物実験によりその原因が追 求されてきた。しかしその本態は未だに不明のままで ある. 大腸菌, ブルセラ菌なぞグラム陰性菌の純粋な Endotoxin を静注すると家鬼，ラッテ，犬などの実験 動物では末梢動脈の血圧低下がみられ，続いて閒脈圧が 上昇してくる．この門脈圧立進は Anaphylaxis にみら れる変化である。

しかし Anaphylaxis と Endotoxin Shock が同一の
ものであるとするには血液の㠜固時間, 抗体産生の面な ぞからみて無理がある様に思う。

実験的に Endotoxin Shock を起させた動物に Shwartzman 反応の現れる点から，Shwartzman 反応がその 原因であると考えるものもいるが未だ不明の点が残され ている. 動物実験による Endotoxin Shock と人の Bacterial Shockをその症状において比較すると犬の Endotoxin Shock では腸管系の症状で始まり, 人のBacterial Shock では悪感戦慄で始まる。 また前者に於ては血中 白血球は減少し，後者では増加する，またへマトクリッ 卜值は前者では上昇し，後者では変動をみないなどの 点で極めて 対照的でありこの両者を同一のものとして よいかどうかも疑問のあるところである ${ }^{39140)}$. 要約すれ ば, Bacterial Shock は Endotoxin によつて起るもの かどうか，末た起るとするならその反応は Shwartzman reaction を介するるのか，あるいは Anaphylaxis に よるものか，これらに対する統一された見解は現在では 見当らない.われわれは Bacterial Shock と考光られる 
2 例を経験したので，これらの症例を報告すると共に文 献的な考察を加えてみたいと思う。

\section{自家経験例}

症例 $1: 77$ 才, 男, 無職.

初診年月日：昭和 41 年 4 月 9 日.

主訴 : 完全尿閉.

入院時診断 $:$ 前立腺肥大症.

家族歴：特記すべもことなし。

既往歴 $: 10$ 年前虫垂切除術.

5 年前より気管支喘息.

現病歴: 約 4 年前より遅延性排尿があり，李た約 2 年 前より頻尿，排尿終末時に不快感があつた。 昭和 41 年 4 月 8 日夜完全尿閉を来たし，某医にて導尿を受け，4月 9 日当科に入院した。

現症：体格中等度, 栄養稍々不良, 眼䀫結膜に中等度 の貧血を認めた. 心音は低いが清. 左肺に笛声音を聴取.

腹部はやや陥凹，柔，回盲部に虫垂切除の瘢痕があ る．四肢には異常所見認めず．脈搏 $92 /$ 分，調律整，稍 々小, 緊張やや弱. 血圧 $160-100 \mathrm{~mm} \mathrm{Hg}$.

局所所見 : 両側腎共に触れず, 陰茎, 睪丸, 副孟丸, 精管いずれにも異常を認めない。

前立腺は超鷄卵大，弾力性で表面平滑，正中溝は触れ ない。

\section{入院時検查成績}

血液及び血液化学的所見 : 血色素含量 $91 \%$, 赤血球数 $431 \times 10^{4}$, 白血球数 4,800 , 赤沈 1 時間值 $18 \mathrm{~mm}, 2$ 時 間値 $47 \mathrm{~mm}$, 出血時間 1 分 0 秒，凝固時間 10 分 0 秒，血清 総蛋白量 $7.0 \mathrm{mg} / \mathrm{dl}, \mathrm{A} / \mathrm{G}$ 比 $0.88, \mathrm{Al} 46.9 \%, \alpha_{1}-\mathrm{G} 4.0$ $\%, \alpha_{2}$-G 9.6\%， $\beta$-G $9.3 \% ， \gamma-\mathrm{G} 30.1 \%$, 血清電解 質 $\mathrm{Na} 129.9 \mathrm{mEq} / \mathrm{L}, \mathrm{K} 4.12 \mathrm{mEq} / \mathrm{L}, \mathrm{Cl} 111 \mathrm{mEq} / \mathrm{L}$, $\mathrm{Ca} 9.8 \mathrm{mg} / \mathrm{dl}$ ， P 3.3mg/dl, 血中 $\mathrm{CO}_{2} 58.5 \mathrm{Vol} \%$. 酸 オスファターゼ0.18 B L 単位,

腎機能検查 : 残余窒素40mg/dl, P.S.P 試験15分值40\%， 120 分合計値 $70 \%$ ，濃縮試験最高比重 1026.

肝機能検查: アルカリフォスファターゼ 4.6 Bodansky 単位, GOT28単位, T.T.T. 4.4単位.

血清梅毒反応：Wa-R（緒方法）（十），凝集法（緒方 法）(+), VDRL沈 (+), R P C F (+).

尿所見 : 淡黄色, 蛋白 $($ 一), 糖 $(+)$, ウロビリノーゲン (正), 赤血球 ${ }^{0 \sim 1} / 1$ 視, 白血球 ${ }^{1 \sim} / 1$ 視, 上皮 (一), 円柱 (一), 細菌(一).

レ線学的所見：腎部単純撮影では異常なく, 膀腅部単
純撮影で前立腺の膀脱内への突出像がみられる，尿道造 影では後部尿道の延長と拡張がみとめられる。

経過：前立腺肥大症があり, 以前より脈搏欠滞，時に は胸内苦䦓を訴光, E.K.G 所見では洞性調律, 比較的 低電位差の傾向がみられた。自排尿困難のために，持続 導尿を行つて扮り, 発作直前までは尿中白血球を多数, 大腸菌 $10^{7} / \mathrm{cc}$ を認め38〜39. $3^{\circ} \mathrm{C}$ の発熱をみていた.

しかしこの当時は胸内苦悶を訴えるが，特に全身状態 には著変なく,ゆつくりではあるが散歩も可能であつ た. ネラトン抜去24時間後に便所の中でショック状態に 陥入り, 意織混濁, 言語障害, 顔面蒼白を来たし, 瞳孔 は円かつ刘照的で対光反射は正常, 心音は低く, 不整で あつた。

四肢の硬直著明で腱反射はすべて充進していたが，病 的反射は認められなかつた. 血圧は $70 \sim 50 \mathrm{~mm} \mathrm{Hg}, \mathrm{GOT}$ 60 単位を示し, この時の心電図は高度の心不全を来し, 発作性上室性頻搏, 心房細動を示した。

直ちに Digitalis 1.2mg/日，Neophyllin $0.9 \mathrm{~g} /$ 日， Persantin 20mg/日, Effortil 30mg/日 Noradrenalin 3 mg/日, Hydrocortisone 100mg/日，抗生物質は Chloramphenicol (CP) $1 \mathrm{~g} /$ 日，輸液 2,500cc/日，を投与寸 ると共に酸素吸入を行いShock に対処した。この日の 尿量は 250cc(1014)，翌日は 750cc（1010),であつた。

Shock 後 2 日血圧も回復し, 尿量は $3,500 \mathrm{cc}$ (1006) と 増加した。（表 1 )

尿中には依然として大腸菌 $10^{8} / \mathrm{cc}$ を認め，GOTは 135 B L 単位と増加している。

血中白血球 13,000 （好中球 $79 \%$ ）を示し, Shock 後 5 日目に Hertinfusion bouillon 培盖で血中に尿中と同型 の大腸菌を認めた. Shock 後10日目では尿中白血球およ び大腸菌は陰性化し，GOTも30単位と発作前の值に回 復した。また残余窒素は発作前と殆んど変化はなく経過 している.

Shock 後80日目に恥骨上前立腺剔除術を施行した。 術前の検査成績

血液抢よび血液化学的所見：血色素含量 $57 \%$, 赤血球 数 $303 \times 10^{4}$, 白血球 9,200 , 血清電解質 $\mathrm{Na} 141.8$ $\mathrm{mEq} / \mathrm{L}, \mathrm{K} 4.28 \mathrm{mEq} / \mathrm{L}, \mathrm{Cl} 108 \mathrm{mEq} / \mathrm{L}, \mathrm{Ca} 10.2 \mathrm{mg} / \mathrm{dl}$, P $3.4 \mathrm{mg} / \mathrm{dl}$, 血清総蛋白量 $7.0 \mathrm{~g} / \mathrm{dl}, \mathrm{N} \mathrm{P} \mathrm{N} 28 \mathrm{mg} / \mathrm{dl}$, で あつた。

腰椎麻酔の下で手術を行い, 術中出血量 $22 c c$, 剔出前 立腺 $54 \mathrm{gr}$ ，手術経過時間25分と極力患者に括よぼす手術 侵襲を少なくした。 
表 1 症例 1

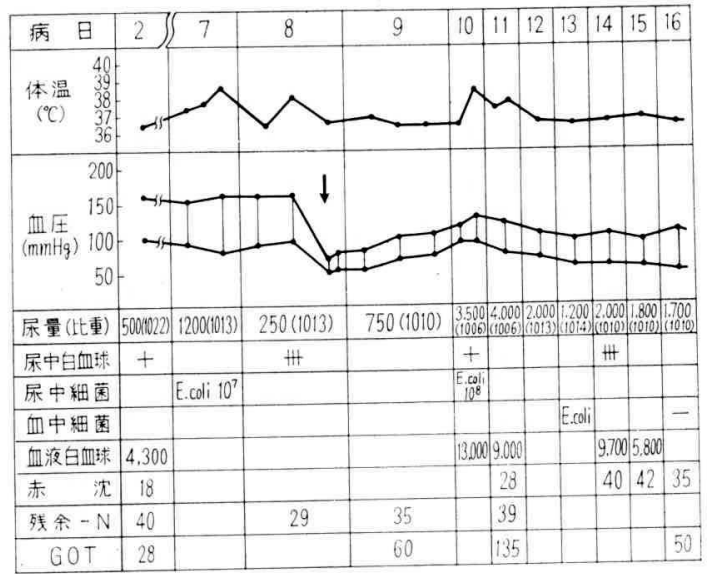

術後 4 日目に血中白血球 $25,000, \mathrm{~N} \mathrm{P} \mathrm{N} 104 \mathrm{mg} / \mathrm{dl}$ と 上昇したが 10 日目は夫々 $7,800,73 \mathrm{mg} / \mathrm{dl}$ と徐々に下降し た. 然し午ら食欲不振が強く, 全身状態は悪化し，14日 目には血清総蛋白量 $4.2 \mathrm{mg} / \mathrm{dl}$, 血中白血球 14,200 と増 加, 血清電質は $\mathrm{Na} 118 \mathrm{mEq} / \mathrm{L}, \mathrm{K} 3.93 \mathrm{mEq} / \mathrm{L}$. と減少 し，17日目に末梢循環不全のために死亡した。

病理解剖学的㧍よび組織学的診断および所見

限局性化膿性腹膜炎

\section{化膿性膀胱炎括よび膀朕周囲炎}

前立腺剔出後膿揚形成

感染脾

ネフローゼ（尿細管上皮の水腫性変性）

浆液線維素性胸膜炎（両側）

\section{大動脈硬化症}

体格中等度, 栄養状態不良, 皮有蒼白, 浮腫はない。 表在性リンパ節は米粒大, 腹腔内には混濁した淡褐色 腹水 $100 \mathrm{cc}$ がある.腹膜は前下腹部より膀胱上面にかけ て出血斑を伴い充血性粗精である. 病理組織学的には, この部は化膿性腹膜炎の像を呈す。両側胸腔内には左側 $150 \mathrm{cc}$, 右側60ccの黄色透明な胸水があり, 左肺尖部は 胸腔壁と線維素性に癒著する.

心： $290 \mathrm{~g}$, 冠状動脈蛇行し, 部分的に軽度の硬化が ある。心筋層には小壊死栄が散在性に認められる。

肺 : 左肺 $230 \mathrm{~g}$, 右肺 $290 \mathrm{~g}$, 両側共に胸膜が軽度の 円形細胞浸潤を伴い線維性に肥厚しているほかは著変が ない。
脾 : $100 \mathrm{~g}$, 表面に線維素折出がある, 割面は暗赤色 でやや軟かく膨隆する．リンハ濾胞は不明膫である．組 織学的には細絧細胞および 組織球性細胞の增殖が著明 で, 赤血球貧喰像も認められる.リンパ濾胞は縮小して いる.

腎: 左腎 $190 \mathrm{~g}$, 右腎 $180 \mathrm{~g}$, 雨側共に表面は多少粗 大凹凸不平で, 数コの小指頭大までの尿囊腫がある.

割面では皮質やや荅白，䯣質赤色で，皮質の厚さ 0.6 一 $0.7 \mathrm{~cm}$ である. 腎㙉, 尿管には異常がない. 組織学的 には尿細管主部の上皮細胞が著明に水腫性に腫張変性 し，尿細管主部内腔は狭小化している，系球体は硝子化 したものが散見される以外著変はない, 間質は多少浮腫 状で，主として円形細胞の浸潤が中等度にある. 髄質で は毛細血管が多少充血性で, 部分的に下部尿細管内に尿 円柱を見る．腎中小動脈には部分的に内膜の線維性肥厚 がある。

副腎：肉眼的に変化を見ない，組織学的には球状帯は やや簿くなり, 束状帯外側に濃染した大形の核が散見さ れる. 束状带の中間部に, 数ヶないし十数ヶの実質細胞 脱落巣が所々にある．この様な部位には変性膨化した明 るい実質細胞が若干残存しており, 軽度のリンパ球様細 胞浸潤を伴つている。しかし大部分の実質細胞には著明 な変化を認めない。

膀阮 : 膀胱前壁には手術創があり，2 ケ所で結紮縫合 されている. 肉眼的にも, 組織学的にも, 化膿性膀胱炎 および膀脂周囲炎の所見を示す。

前立腺：筋膜は残存し，腺質部はほとんど手術的に剔 出されている。組織学的には残存部は強い化膿性炎の像 を呈す。

その他蔵器には著変を認めない。

腎: 尿細管主部上皮の著明な水腄変性

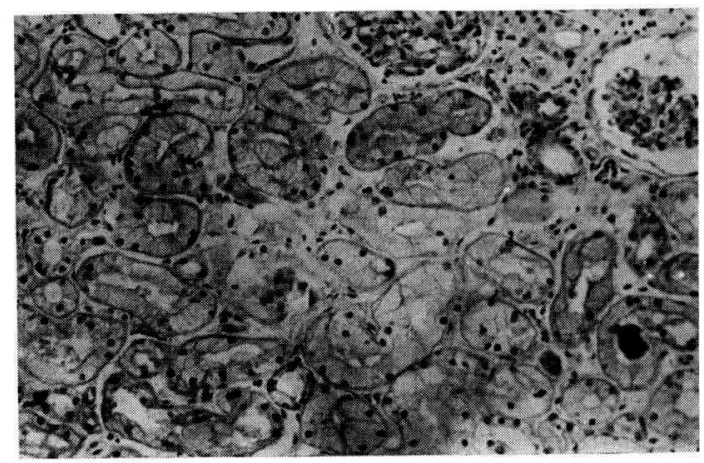


症例 $2: 72$ 才 男 農業

初診年月日：昭和 41 年 5 月 13 日.

主訴: 尿線細小及び尿線中絶.

入院時診断 $:$ 膀胱結石.

家族歷 : 妹 50 才で肺結核にて死亡，他は特記すべきこ となし。

既往歴：約 30 年前より気管支喘息あり，昭和 35 年 9 月 前立腺肥大症にて前立腺剔出術. 昭和 37 年 7 月膀脱砕石 術を受けたことがある。

現病歷：昭和 41 年 4 月下旬上り尿線細小，尿線中絶を 来すようになり，同年 5 月15日当科を受診し膀腃結石の 診断のもとに 5 月 25 日入院した。

現症 : 体格栄養共に中等度, 眼䀫眼球結膜には異常な く，頝部リンパ腺は触れない，胸部理学的所見では，心 は左右に 1 横指肥大し, 心音は低いが清, 全肺野に笛声 音を聴取し，左右前下野には小水泡音を聴取した．腹部 は平担で，脐下より恥骨上部にかけて手術洀痕を認め る。触診上では軟かく，腫瘤は触れない。肝，腎，脾は ともに触れず，下腿に浮腫は認めない。血圧 170-90 $\mathrm{mm} H g$, 脈搏68/分, 整, 緊張良好。陰茎, 粹丸, 副睪丸 飞は異常はなく前立腺は胡桃大，弾性硬，中心部は凹凸 不平で正中溝は触れない。

\section{入院時検查成績}

血液㧍よび血液化学的所見：血色素含量 $95 \%$, 赤血球 数 $515 \times 10^{4}$, 血小板数 $13 \times 10^{4}$, 白血球数 6,900 (好中 球 $48 \%$ ), ヘマトクリット值 $48 \%$, 出血時間 3 分 0 秒, 凝 固時間 8 分 0 秒，血清電解質 $\mathrm{Na} 146 \mathrm{mEq} / \mathrm{L} ， \mathrm{~K} 4.28$ $\mathrm{mEq} / \mathrm{L}, \mathrm{Cl} 110 \mathrm{mEq} / \mathrm{L}, \mathrm{Ca} 10.7 \mathrm{mg} / \mathrm{dl}, \mathrm{P} 3.2 \mathrm{mg} / \mathrm{dl}$, 血 清総蛋白量 $6.1 \mathrm{~g} / \mathrm{dl}, \mathrm{A} / \mathrm{G} 0.86, \mathrm{Al} 46.3 \%, \alpha_{1}$-G 4.9 $\%, \alpha_{2}-\mathrm{G} 7.4 \%, \beta-\mathrm{G} 12.1 \%, \gamma-\mathrm{G} 29.3 \%$.

肝機能検查: アルカリフォスファターゼ2.1Bodansky 単位, GOT 25 B L 単位, C C F (士), T.T.T 2.1単 位.

尿所見: 黄褐色混濁屴り, $\mathrm{pH} 7.0$, 蛋白 $(+)$, 糖(一), ウロビリノーゲン (正), 上皮 $(+)$, 円柱 $($ (一), 燐酸塩 (十),細菌 (一).

腎機能検查：血清残余窒素 $23.0 \mathrm{mg} / \mathrm{dl}$ ，濃縮試験最高比 重1019，P S P 試験15分值 5\%，2 時間合計値 $50 \%$.

泌尿器科的検查所見 : 膀胱鏡所見は揊指頭大の表面凹 凸不平な茶褐色の結石を 2 ケ三角部に認め, 三角部から 後部にかけての粘膜および䅡部粘膜に高度の充血を認 め，左右の尿管口は異常はなく，青排泄試験は右初発 4 分 50 秒, 濃染 5 分 50 秒, 左は排泄されず.

腎膀胱部単純撮影では膀胱部に 3 ケの類円形結石像を
認める，各々の計測値は $3 \times 1.5 \mathrm{~cm} ， 1.5 \times 1.0 \mathrm{~cm} ，$ およ び $1.0 \times 0.7 \mathrm{~cm}$ であつた。排泄性腎孟撮影では左腎は 5 分，10分で造影され著明な変化は認めないが，右腎は排 泄は認められるが，腎孟，腎杯像は判然とせず。遷延性 排泄性腎孟撮影では，腎孟，腎杯は両側とも著変は認め られない，尿道造影では特に尿道の狭窄は認められない が，前立腺床に結石が嵌入した像を呈する。

経過：膀胱結石に対し，結石溶解剂による膀胱潅流を 施行し，海流 3 時間後，突然に悪感を伴つた， $38.2^{\circ} \mathrm{C}$

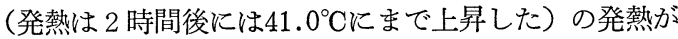
あり，胸内苦悶，喘鳴，咳嗽を訴兄，30分後に喘鳴，峐 嗽が強度となり，顔面，上肢にチアノーゼが出現した． 脈搏数 100 /分, 整, 緊張良好, 胸部理学的所見は肺野全 体に笛声音，軋轢音を聴取した。音は聴取出来ず，そ の後血压は70-0 mm Hgまで下降し，心電図の所見では強 度の心不全を呈した. Digitalis $1.2 \mathrm{mg} /$ 日，元の後 $0.4 \mathrm{mg}$ の維持量を続け，Neophyllin $1.4 \mathrm{~g} /$ 日, Persantin10mg/ 日, Effortil 10mg/日，抗生物質（発作日 C P 2000mg， Cephaloridine [CER]1000mg，その後10日間C E R 1000 mg投与)，副腎皮質ホルモン（発作日Ｈydrocortisone 1000mg，その後暫減し10日間で中止），輸液（2000～ $1000 \mathrm{cc} /$ 日)，を投与して経過観察中であつたが，発作後 約20時間で血圧は約 $110 \sim 70 \mathrm{~mm} \mathrm{Hg}$ 程度に回復し，脈搏数 もやや減少し，90/分，前後となつた。

発作後の検查成績では，第一日目には血液細菌培養陰 性, GOT 290 B L 単位, 白血球数 23,400 , 血清電解質

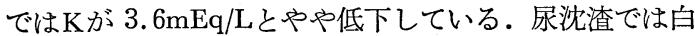
血球無数，球菌が $3 \sim 4 / 1$ 視第 2 日目には血中白血球 数 24,600 , 赤沈 1 時間值 $35 \mathrm{~mm}$, 尿所見では白血球は無数, 球菌 $3 \sim 4 / 1$ 視, 第 3 日目にはGOT 40 単位, G P T 25 単位, 赤沈 1 時間值 $49 \mathrm{~mm}$, となつた。 その後上記薬剤 投与にて経過を見た．発作後 4 日目に，舌苔及び口唇， 前胸部に発疹を来たした，舌苔よりの培養により，カン ディダを検出した。発作後，10日目まで抗生物質を続け その後サルファ剂に変更し, 又発疹の治療には，ゲンチ ヤナヴァイオレットとルゴール液を舌苔に，口居，前胸 部には副腎皮質ホルモン剤を敍布した。

発疹及び舌苔は出現後約10日目より軽快し始め，20日 目にはほぼ全治し，発作後34日目に局所麻酔にて膀脂切 石術を施行した。結石成分は炭酸塩，燐酸塩であつた。

発作後の検査成績は表のごとくである．この症例では 症例 1 と比較すると，血中に菌を認めることが出来ず， 尿中にも大量の菌は認めていない。また血清残余窒素は 
表 2 症例 2

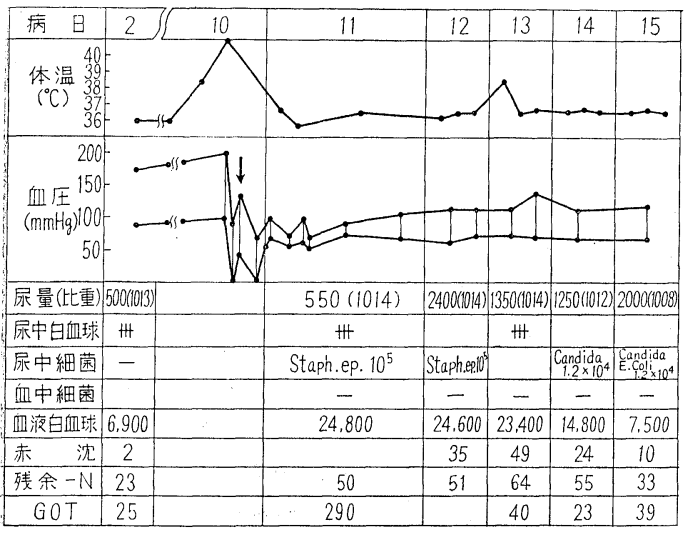

軽度の上昇を示し，ジギタリスの影響と思われるが，血 清電解質の中でK低下がみられたのみであつた。

\section{考按}

泌尿器科的操作後, 特に逆行性腎盂撮影, 経尿道的操 作或は前立腺剔除術後など留置カテーテルを抜去した後 に，一過性の発熱あるいは囷血症をみることは泌尿器科 領域に㧊いて経験し報告されている。われわれはあらか じめこの発熱に対処し, 抗生物質, サルファ剂を投与し て子防に勉めるのであるが，時として重篤なる尿路感染 症または敗血症へと移行することがある．特に老人，小 児にこの傾向が強く, 術後の全身状態の衰弱に相末つて 各種の合併症を若起しショック状態に陷り急速に死の転 归をとることがある。

1）原因

Bacterial Shock が Endotoxin によるものであるか, あるいは Bacteria 自体が毒性を持つているか性不明で あるが，Weil ら されて作用するものであろらと述べている。

実験的に Endotoxin 注入後末梢静脈扢よび V. Cava は血圧の下降を示し，同時に門脈圧の上昇を認めてい る. この原因は腹部系からの静脈血が肝静脈の Contractionにより噛滞するために心に返る血流量が娍少し，末 梢血圧の低下を来たすといわれ，渋沢 ${ }^{19)}$ はこの肝内血管 の反射的収縮は A T P やセロトニンによるものであろう と述べている.

Bacterial Shock にて死亡した人の剖検所見は，腎皮質 壊死 $^{14)}$ 副腎皮質壊死 ${ }^{14)}$ ，腸管の出血，填死などが認めら れるが，反対に臨床的には完全な Bacterial Shock の症 状を呈し年ら, 病理組織学的に軽度の腸管出血を認める
にすぎないもの，あるいは特徵的な変化を欠くものもあ り，組織像には相当の程度の差があることが同われる。

Endotoxin Shock 即ち実験的に動物に Endotoxin を 注入することにより，動物を死に至らしめ，その病理組 織を Bacterial Shock と比較すると, 両者とも肺に於け る高度の出血と壞死像, 気管枝, 平滑筋の疼孪, 腸管の 充血浮腫および壊死 ${ }^{35)}$, 腎皮質壊死が認められる.

病理組織学的には Endotoxin Shock と Bacterial Shock は大さな相異はないと考えられる。

これらの原因としては Weil の云う如く， Endotoxin の作用が最も疑われるが，この Endotoxin の作用機序 については Shwartzman 反応を介するか，あるいは抗 原抗体反応による Anaphylaxis なのか意見が分かれて いる.

a) Shwartzman reaction を原因と考学る者は実験的 に Fibrin 栓塞による腎皮質壊死を起すのに Shwartzman reaction が応用されることを根拠にしている.

たとえば家鬼の場合 $0.2 \mathrm{mg} / \mathrm{kg} の$ Endotoxin を24時間 の間隔を执いて 2 度に亘り静注すると腎皮質壊死を起 しうること，また Stetson ${ }^{27)}$ は Shwartzman 活性を示 寸物質は試験管内でも生体内でも血小板掞よび白血球の 集簇を起させる能力をもち，このために栓塞を起すと述 べているが，住友 ${ }^{28)}$ \& Shwartzman 濾液は白血球血小 板の集簇を起したと述べている.

Good $^{7)}$ らによれば Endotoxin 注入後 $2 \sim 4$ 時間後 に白血球，血小板の集簇が起り所謂 Leucocytoplatelet thrombus を形成し続いて出血壊死へと移行すると述へ ている。また臨床的に Graber ${ }^{8)}$ は火傷後 Seratia martescens の感染した症例を剖検して Generalized Shwartzman reaction を認めたと述べている. Mc Keyら ${ }^{16)}$ Bacterial Shock を起した 7 例について病理組織所見を 詳細に報告しているが，7例中 5 例に Shwartzman reaction の場合に一致する形態学的変化を認めている.

然し乍ら Shwartzman reaction 説に対して反対の事 実もある. Endotoxin 大量を家鬼に 1 回静注して数時間 後に全く病理解剖学的に変化を起させずに死に至らしめ たこと ${ }^{16)}$ または，肺に高度の出血像と壊死像を示した 住友の例などから所謂 Endotoxin Shock は Shwartzman reaction の基本である 2 段階に亘る Endotoxin 投 与が必ずしも必要でないことが伺われる，あるいは，臨 床的に Bacterial Shock にて死亡した 7 例の剖検所見の なかで，副腎に充血像を認めたもの1例，腎皮質に病変 
のあつたものはなく，腸管に 1 例軽度の充血をみたにす ぎなかつたといら報告もある。乙れは Bacterial Shock の発生原因として Shwartzman reaction の関与が少な い場合のあることを示唆している.

b) Anaphylaxis

動物性蛋白, 植物性蛋白抆よび細菌性蛋白は Anaphylaktogen となりうる。実験的に血清，乳汁，卵白など を使用して Anaphylactic Shockを起すことは周知のこ とである。

この場合の病理学的所見は腸管, 肺などに充血, 浮腫 を認め，気管枝，平滑筋に疼挛を生ずることが一般であ る.

実験的に Endotoxin Shock にて死に至らしめた動物 の病理学的所見は上述したごとく Anaphylactic Shock の場合の組織所見とよく一致する．然しながら Weil ら ${ }^{35}$ によれば Endotoxin Shock の特徵は腸管系に強い反 応を認めることであり，Anaphylaxis の場合はむしろ肺 に強い反応を現すという。

また血液の凝固時間を比較するとAnaphylactic Shock に於ては血中 Heparin の増量により，その延長をみる が，Endotoxin Shock に於ける Heparin 遊離はまだ確 かめられていない。

また，渋沢 ${ }^{199}$ も Anaphylaxis では血液の凝固時間延 長を示摘しているが，Endotoxin Shock ではその延長 が顕著ではないと述べている。

2）年令，性

性別では $90 \%$ が男性であり, 年令では若年者と高年者 にピークがみられる．61才以上が29例中 19 例 $65.2 \%$ ，末 た死亡率は71.4\%の高率にのぼつている.

表 3 Age, Sex and Outcome of 29 Patients with Shock and Renal Failure

\begin{tabular}{|c|c|c|c|c|}
\hline \multirow{2}{*}{ Age } & \multicolumn{2}{|c|}{ Sex } & \multirow{2}{*}{ Total } & \multirow{2}{*}{$\begin{array}{c}\text { Number } \\
\text { Died }\end{array}$} \\
\hline & Males & Females & & \\
\hline $0 \sim 10$ & 3 & 0 & 3 & 2 \\
\hline $11 \sim 50$ & 2 & 0 & 2 & 1 \\
\hline $51 \sim 60$ & 4 & 1 & .5 & 3 \\
\hline $61 \sim 70$ & 6 & 2 & 8 & 7 \\
\hline $71 \sim 80$ & 4 & 0 & 4 & 4 \\
\hline $81 \sim 90$ & 7 & 0 & 7 & 4 \\
\hline & 26 & 3 & 29 & 21 \\
\hline
\end{tabular}

Spink, W.W. (1962)

\section{3）基礎疾患}

Weil ら ${ }^{377}$ によれば泌尿器疾患患者が最も多く，149例
中 $24 \%$, 糖尿病患者 $21 \%$, 肝疾患患者 $18 \%$, 敗血症性流 産16\%，肺炎 9\%，その他 $12 \%$ となつて抢り $12 \%$ 中には 腫瘍などが含まれている。また，Weil らによれば手術 あるいはその他の操作後ショツクを起こすまでの時間は 16時間であり，回復したものでショック状態の継続時間 は平均 2.3 日, 死亡したもので 2.0 日であつた。 また 1 例は22日間も低血圧の状態が続いたが回復したものもあ り，Shock を脱した31例の中でも13例が循環障害のため に1～16日に死亡している. そして Shock に続発した 腎機能障害のために死亡したものは 2 例しかなかつたと 述べている。

4）臨床症状扮よび臨床所見

Weil $\check{ら}^{38)}$, Weil $ら^{37)}$, Udhoji $5^{34)}$, Weisbren ${ }^{39}$ は多くの臨床症状を列記しているが，次の11項目に総括 される。

i) Sudden elevation in temperature

ii) Hypotension $85 \sim 90 \mathrm{~mm} \mathrm{Hg}$ 以下

iii) Tachycardia (not a characteristic finding)

iv) Tachypnea

v) Pallor or cyanosis

vi) Warm and dry skin

vii) Cold and clammy skin

viii) Mental confusion (stupor, coma, instantaneous collapse)

ix) Loose stool

x) Vomiting

xi) Abdominal pain

また教室の津曲は Bacterial Shock と思われる症例で 上述の症状に加兄て両下肢の激痛があつたと述べてい る.

\section{検查所見}

一般的な炎症疾患でるみられるようなものであり，特 別の所見といらものは認められないが，これらを列記す ると，i）血中白血球増多，ii） GOT上昇，iii）血清了 ミラーゼ值上昇，iv）血清ビリルビン上昇，v）血中残 余窒素上昇，vi）代謝性アチドーシス, vii）E.K.G：の 変化などであり，白血球増多も初期に於てはむしろ減少 の傾向があり，発作後 $4 \sim 8$ 時間後に増加してくるとい う。そしてその数は $13,000 / \mathrm{mm}^{3}$ 以上しかも好中球が $80 \%$ 以上を占めるという。

Forkner ら ${ }^{4)}$ は血小板の減少を記載してあり，Endotoxin Shock 飞於牥る Leucocyto-platlet thrombus 形成 
による血小板減少を考兄併せると興味のあることであ る. また Shock 時に於ては当然乏尿に傾くが血清電解 質 $\mathrm{Na}, \mathrm{Cl}, \mathrm{K}$, などマは変動は認められず，血液のpHに も, ヘマトクリット值にも異常所見は認められないとい

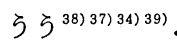

E.K.G. 所見では Weil ら ${ }^{377}$ が比較的詳細に報告して いるのでそれらを引用すると表 4 亿示す如く Bacterial Shock 独特の所見はなく心筋梗塞を疑うのが妥当な感じ を受ける.われわれの症例でも発作直後の E.K.G. で発 作性上室性頻博, 同時にGOT上昇を認め, 老人性の動 脈硬化拉よび梅毒の既往歴があるので，感染による高熱 が刺戟となり意識障害を伴つた心筇梗塞を併発し，発作 性頻博，心房細動を惹起したものでないかとも考えた。

表 4 Electrocardiographic Finding during Shock (102 Patients)

Myocardial ischemia and injury

Number

$\mathrm{T}$ wave abnormalities (44)

S-T segment abnormalities (33)

Myocard infarction, recent and old (12)

Cardiac arrhythmias

Supraventricular tachycardia (33)

Other arrhythmias (24)

Low voltage

Conduction defect

Ventricular hypertrophy

Electrolyte umbalance

Normal electrocardiogram

\section{9}

57
6
0
9
6
8

Weil, M.H. et al (1964)

5) 細菌学的検查

Weil ら $^{377}$ は内科, 婦人科, 外科, 泌尿器科掞よびそ の他の科に 入院した，394,201例の患者で，Bacteremia を発見したものが 692例（ $0.2 \%$ ）であり，その内訳け は, 内科 $48 \%$, 産科 $27 \%$, 外科 $10 \%$, 泌尿器科 $10 \%$, そ の他 $5 \%$ であつたこと記している. そして Bacterial Shock に陥入つたものが 629例中 169名 (24.6\%) であ り，Weil ら ${ }^{38)}$ は 278例中43例（15.5\%）であつたと述 ベている.

また Shock に陥入つたものの死亡率は Weil ら ${ }^{377}$ は 細菌別に記載して扮り，大腸菌 $76 \%$ ，肺炎桿菌など 86 $\%$, 変形菌 $96 \%$ ，緑膿菌83\%，パラコロン $86 \%$ ，サルモ ネラなどは $100 \%$ とて捛り，変形菌感染に注意を促し ている.

また Weil ら ${ }^{38)}$ は Shock に陷入つた43例中死亡した もの 28 例 $(65 \%)$ で，2 種以上の混合感染の時に死亡率

が82\%にもなつたと述べている。

検出菌の頻度は Weil ら ${ }^{377}$ にれれば大腸菌 $49 \%$ ，肺炎 桿菌など24\%，変形菌14\%，緑膿菌 $7 \%$ ，パラコロン 4 $\%$ ，サルモネラ $1 \%$ ，同定不可能菌 1\%となつている.

6）年代別に見た死亡率

Maiztegui ら ${ }^{13)}$ は1935年から1962年までの Bacteremia の死亡率を年代を追つて調べている. 表 5 にみられるよ うに，1935，1957〜1958，1961〜1962年にピークがあ り，その逆に1951年は著しく減少している．抗生物質， 副腎皮質ホルモンなどの使用と考光併せると興味のある ことである。

表 5 Mortality from Gram-Negative Rod Bacteremia

\begin{tabular}{|l|c|c|c|}
\hline \multicolumn{1}{|c|}{ Author } & Year & $\begin{array}{c}\text { No. } \\
\text { of cases }\end{array}$ & $\begin{array}{l}\text { Percent } \\
\text { morta- } \\
\text { lity }\end{array}$ \\
\hline Finland et. al ( 3) & 1935 & 34 & 44 \\
\hline Weisbren (14) & 1951 & 29 & 17 \\
\hline $\begin{array}{l}\text { Spittel. Martin and } \\
\text { Nichols (12) }\end{array}$ & $1940 \sim 54$ & 137 & 22 \\
\hline Finland et al ( 3) & 1957 & 178 & 56 \\
\hline $\begin{array}{l}\text { McCabe and } \\
\text { Jackson (10) }\end{array}$ & $1951 \sim 58$ & 173 & 42 \\
\hline $\begin{array}{l}\text { McHenry. Martin } \\
\text { and Weltman (11) }\end{array}$ & $1955 \sim 59$ & 113 & 30 \\
\hline Maiztegui et al ( 1) & $1961 \sim 62$ & 100 & 55 \\
\hline
\end{tabular}

Maiztegui, I.I. et al. (1964)

\section{7）感染経路}

Weil ら ${ }^{377}$ は79例について原因を調べて抢り，骨盤内 手術後が $43 \%$ ，尿路系に操作を加究た後が $39 \%$, 瘡傷処 置 $8 \%$ ，腹部手術 $1 \%$ ，その他 $2 \%$ となつている。また Talbot ${ }^{29)}$ は 8 例の術後, Bacterial Shock を報告しその 内訳は 2 例が腹部藏器を剔出したものであり，1 例が死 亡している. 他の 6 例は泌尿器科的手術を行つたもので あり, T UR 4 例, 恥骨後式前立腺剔出術 1 例, 包茎に よる慢性尿毒症のために, カテーテル留置を行つた例で ある、TURの 1 例が死亡している.カテーテル留置は 7 例であり， 7 例中 5 例迄がカテーテルの拔却後にショ ツクを起したものである。このことはわれわれ泌尿器科 医のみならず一般医家にとつても十分の注意を払う必要 があろうと思う。

\section{8) 病理組織学的検索}

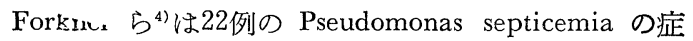
例に病理組織学的検尜を加えている. そして, 肺, 皮 
膚，口に病変が多く，腎，肝，腸管，リンパ腺などはあ まり変化を受けていないと述べている，病変部では組織 の小血管に急性炎症ないしは壊死を認めているが，これ らは出血，栓塞によるものとし，また Pseudomonas 感 染の特徵は血管壁での菌集簇形成 と血管壁の変性であ り，しばしば限局性に現われると述べている。

Weisbren $ら^{40)}$ は 7 名の Bacterial Shock にて死亡し たものの剖検では腸管に殆んど病変を認めず Endotoxin の動物実験による腸管病変とは対照的であつたと述べて いる.そしてこれらの患者の腎静脈に Schwartzman 反 応の特徵である栓塞が 認められなかつたことは Shock の原因が Schwartzman 反応によるものでないことにな ると述べている.

われわれの症例中剖検した第 1 例では，剖検時には腹 膜炎, 感染脾などの炎症病変が目立ち, 肺拉よび副腎, 腎皮質には血管壊死, 出血など Shwartzman 反応が起 つたことを裏づける所見は認められなかつた。また Shock 時にみられる末梢循環系のうつ血や臓器の浮腫もな く，腎の組織学的な変化は所謂ショック腎のそれとは異 なるものと考えられた，これは前述の如く Bacterial Shock の剖検所見の報告には相当のばらつきのあること， 更に本例では Shock 状態に陥つてから死亡までに 100 旧近い日数が経過していることが，病変出現の様相に影 響したであろうことも考慮しなければならない。

しかし感染状態が最後まで持続していたことは剖検所 見が示している. 副腎にみられた小壊死巣はこの感染に 上る侵襲が影響しているものかもしれない。

9）臨床経過

Udhoji $ら^{34}$ は Bacterial Shock 16例を心博出量, 血 液循環速度と末梢血圧の 3 点から 2 つのグループに分れ ると述べて抢り，第 Iグループは心拍出量低下，循環時 間延長，末梢血圧正常，第II グループは心拍出量，循環 時間は正常，末梢血圧の低下を指摘している. そして， 第II グループは肝硬変, 動脈硬化などの合併症を持ち, 血中白血球数, GOT, G P T, Serum amylase などで はグループIに比して重症を思わせる変化がある.

われわれの症例は Udohji の分類に従えば，Iにも II にも入り，ぞちらとも云えないが，経過が緩除であつた 点から第Iグループに属するものではないかと思う．

10）われわれの症例の診断根拠

さきに Bacterial Shock 飞対する諸家の報告を年令, 性, 基礎疾患, 臨床症状, 検査所見, 感染経路なぞにつ
いて述べたが，決定的な診断根拠となるものはなく，総 合的な面から考慮しなければならない，われわれの 2 例 はいずれも男性老人であり泌尿器科的疾患をむつてい た。 そして Shock に陌入る前に尿道操作を加えて拉 り，高熱を発した直後，1例では悪感戦慄を伴つて，劇 的な血圧低下をみ，頻博，呼吸浅迫，チアノーゼ，1例 では意織障害を来たした。 そして血液所見では白血球は 13,000 (好上球 $79 \%$ ). $24,000 / \mathrm{mm}^{3}$ と増多を示し，1 例 では血中に大腸菌を検出している。またGOT值は夫々 135，290 B L 単位と上昇し，E.K.G. では Weil らの 云う myocardial ischemia and injury の所見を示した ことなどである.

11）治療

i) 抗生物質

感染菌の同定あよび薬剤耐性を検査することは勿論重 要なことであるが, Shock に際し臨床的にはその検查結 果を待つて抗生物質を選ぶことは当然不可能のことであ る. 從つて CP, Tetracycline (TC) など Broad spectrum のものを大量に使用することになる.

腎機能低下が合併するのが一般であるので腎毒性の面 から Kanamycin, Neomycin, Bacitracin などは不適当 と思われる。

我々は症例 1 ではカテーテル留置による尿路感染の予 防の意味で (TC) を $1 \mathrm{~g} /$ 日使用していたが, Shock 後 CP $1 \mathrm{~g}$ /日を静注して経過をみた。 2 日後には $38.4^{\circ} \mathrm{C} の$ 発熱をみているが，耐性検査の結果では CP 耐性であ つた. Shock 後 5 日目に Bacteremia を認めその耐性検 查を待つて CER $1 \mathrm{~g}$ /日静注, Colimycin 100万単位/ 日を併用した結果以後は血中に細菌は認めなかつた.

症例 2 では Shock 当日は Cepharosporin $1 \mathrm{~g}, \mathrm{CP} 1 \mathrm{~g}$, を静注し，翌日からは CER 500mgを12時間毎，毎日静 注し経過を観察した。この場合は全く Bacteremia は認 めなかつた。

渋沢 ${ }^{199}$ は動物実験により抗生物質を十分に与兄ると Shock による死亡率を低下させ，門脈血，末梢血，腹 水，肝などの菌発見率が極めて低いことを指摘してい る。また Fine（1956）の文献を引用して, Aureomycin を実験前から経口的に $5 \mathrm{~g}$ 与光，続いて実験開始と共に $5 \mathrm{~g}$ 与えると Shock 死をま妨れるものが36時間後8 8 \%であると述べている。

これらの実験を併せ考兄ても，大量の抗生物質を投与 
することが望ましいと思う。

Weil $~^{37)}$ は CP 3g, TC 2g, Streptmycin 1g, Polymyxin B $2.5 \mathrm{mg} / \mathrm{K}$ の量を推めてあり，尿量が $800 \mathrm{cc}$ 以 下になる時は適当に減ずるようにと述べている.

ii）抗ヒスタミン，抗セロトニン等

Endotoxin Shock に際しヒスタミン様物質, Serotonin, Catecholamin, Bradykinin などの遊離が確かめられ て拉り，またこれらに対する拮抗剤を投与することによ り Shock をまぬがれた Abernathy ら ら $^{1)}$, Gibbert ${ }^{6)}$ の 実験結果からみて臨床的にも応用されてよいと思う。

iii）酸素吸入

Bacterial Shock 飞より血液循環不全飞陥り四肢, 顔 面にチアノーゼをみることは諸家の報告するところであ る.また Gerbode (1954) の云う如く無酸素症は心停 止，心室細動を招く大きな原因であるとすれば充分な酸 素を与兄て Shock に対処することが必要となる.

iv）輸血扢よび Plasma補給

二次性の Shock 飞対しては輸血, 輸液こそ決定的な 蘇生法であるが， Bacterial Shock はむしろ一次性の Shock であり，全血量が減少したのではなく, Gatch ら によると Endotoxin による Vasomotor control が失わ れ，一時的に Vascular collaps の状態に陥つたもので ある。

Shock 時にみられる 1)血球の末梢偏在即ち Capillary hemoconcentration, 2) Tissue anoxia 3)Metabolism の低下，4)Acidosis, Alkali reserve の低下，5)腎障害， 6)心臓の伝導系機能障害, 7)中枢神経の損傷, など多 くの合併症を惹起する。これらに対処するには輸血或は Plasmaを補うことが必要となる。

実験的に犬で大量の Plasma を投与しているが低血圧 は回復せず，乏尿も継続している。しかし，Mckay ${ }^{16)}$ は血圧の回復が得られる，得られないにかかわらず輸 血, 或は Plasma の補給が必要であると述べている。乙 かしながら輸血量飞関しては触れていず，2，3 の症例 報告より凡その見当をつけるより方法がない. Spink ${ }^{24)}$ ， Mckay $5^{16)}$, Forkner $5^{4)}$, Udhoji $ら^{34)}$ は 1 日量 500 ccの輸血を行つてあり, Spink $^{26)}$ は 1 日量1000 cc の輸血 を行つている.われわれの 2 例では全く輸血には頼らず に軽快したが，重症の場合には当然考慮すべき必要があ ろうと思う。

v）副腎皮質ホルモン療法
Weil $ら^{37)}$, Melby $ら^{177}$ は Bacterial Shock の死因は Adrenocortical insufficiency でない理由として, Shock 時の Hydrocortison の分泌が増加すると同時に A C T H に対する反応が保たれていることを示摘している.

a) 動物実験

McCabe $~{ }^{15)}$, Spink ${ }^{22)}, \operatorname{Spink}^{25)}$, Spink $^{26)}$, Spink $^{24)}$, Bennett $ら^{21}$, Thomas ${ }^{31)}$, Lillehei $ら^{10)}$ は副腎皮質ホル モンの前処置により，犬あるいは他の動物に於て Endotoxin の影響を減ずることを指摘しており，また Spink $^{26 \%}$ は Hydrocortison, Predonisolone などの Glucocorticoid の大量使用は動物の延命効果をあげ腎機能を高め，血圧 上昇に効果があると延べている。

然しながら，彼等は同時に逆の現象即ち，前処置のた めに死亡率を高めることがあると述べている，特に Spink $^{26)}$ は Aldosterone 即ち Mineralcorticoid の場合は 犬，猿の実験であるが，適量なれば延命効果は勿論回復 することもあるが，大量使用（ $0.2 \sim 2 \mathrm{mg})$ では Endotoxin による死を速めるとる述べている.

また Thomas ら ${ }^{301} は \mathrm{~S}$. marcescenstoxin を使用し た家鬼の実験に於てCortison 25mgを連日使用したが Shwartzman reaetion を阻止することは出来なかつたし， また，Cortison で処置した家鬼に 1 回の Toxin を皮下 に注入したことにより，その場所に出血壊死反応を示 乙, 組織学的にも Shwartzman reaction 類似のものを 認めたと述べている。

b) 臨床例

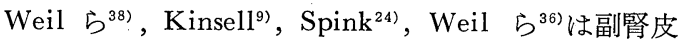
質ホルモンの治療収果を認め，その理由を Endotoxin の Systemic reaction 飞対する抑制効果即ち, 生理的効 果ではなく, 薬理学的効果であるとしている.

$\mathrm{Spink}^{24)}$ ，は副腎皮質ホルモンの大量使用を推めて打 り, Hydrocortison 300〜 500mg, 若し必要なら 500〜 1000mgを 1 回量とし，3〜 4 日間連用することを推奨し ている．そして彼の経験からは好ましから䀦作用は認 めなかつたと述べている。

また Weil ら ら77は Hydrocortison を使用しなかつた 例， $300 \mathrm{mg} /$ 日使用した例と，300 $\mathrm{mg} /$ 日以上使用した例の 3 者について死亡率が夫々 $83 \% ， 85 \% ， 57 \%$ となつたと 述べて，大量使用を推めている.

Shubin $ら^{20)}$ は Hydrocortison 療法は昇圧剤との併用 によりその効果が增すと云い生存率が全く昇圧剤を使用 しなかつたもので $5 \%$ ，僅かではあるが使用したものは 9\%であつたと報告している. Spink ${ }^{23)}$ も犬，猿の実験 
で昇圧剤と Glucocorticoid, Mineral corticoid の併用効 果を確かめている.

然し Margaretten ら ${ }^{14)}$ は脳炎の症例で両側性の副腎 皮質壊死を認めて招り，これが副腎皮質ホルモン療法に より起つたものでないかとさえ述べている。

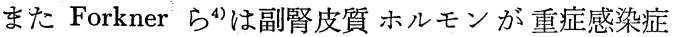
に於て極めて劇的に奏效することがあるが，反対に逆効 果を現わすことがあると述べ注意を喚起している。

vi）その他

a) 昇圧剂

Weil ら ${ }^{37)}$, Udhiji ら ${ }^{333}$ は Adrenaline 作働物質であ る Phenylephrine (Neo-Synephrine), Methoxamine (Vasoxyl), Levarterenol(Levophed) Metaraminol (Aramine)などを使用して抢り，Lillehei ${ }^{2 i)}$ Levarterenol で 前処置した場合犬で Endotoxin 注入後 $120 \sim 140 \mathrm{~mm} \mathrm{Hg}$ の血圧が保てたと述べている.

b) 強心剂

Digitoxin, Acetyldigitoxin, K-Strophantin などは抗 ショツク性であり,われわれも Digitoxin を輸液と併用 して効果を認めた.

c) Adrenaline 作働遮断剂

Lillehei ${ }^{111}$ は Chlorpromazine, Phenoxybenzamine (Dibenzyline) などは効果があると述べている。 また Lillehei ら'は Phenoxybenzamine と Levarterenol を 併用して末梢血管抵抗を弱め心拍出量を増加したと述べ ている.

d) Heparin 様抗凝固剤

Graber $ら^{8)}$ は Dextran sulfate, Sodium polyanethol sulfonate, Sodium polyvinylalcohol sulfonate などを推 めている。

e) THAM (2-Amino-2-hydroxymethyl-1.3-propanediol)

Spink $^{25)}$ は実験的にTHAMにより acidosis が是正さ れ，尿量は增加したが，低血圧は持続 したと述べてい る. またTHAM と Hydrocortison, Metaraminol など 併用すると Shock に対して効果が期待出来ると述べて いる。

\section{f) Angiotensin II}

Del Greco ら ${ }^{3)}$ は Levarterenol, Metaraminol で効果 のなかつたものが, Angiotensin II で奏効したと述べ ているが，これはまだ研究段階であろうと思う。

g）その他

電解質のバランスを乱さない様にまた心への負担を考
慮しながら輸液を行い，同時に組織の代謝機能低下を補 ら意味でビタミン類特に $\mathrm{B}_{1}$ 鼡を投与することは必要と 思われる。

\section{結 語}

1） 2 例の Bacterial Shock と思われる症例を報告 し，いささかの文献的考察を加えた。

2） 1 例は Shock 回復後 80 日目に前立腺剔除術を行 つたが術後17日で死亡した。 Bacterial Shock から完全 に手術に耐兄られるまでの回復にはさらに長期間が必要 であると考觉られた。

3）治療は i）抗生物質の大量投与，ii）昇圧剤，iii） 強心剂，iv）輸液，輸血，v）副腎皮質ホルモンの大量 投与，vi）酸素吸入，なぞを時を俱まらず行うべきであ る.

\section{文献}

1) Abernathy, R.S. et al.: J. Leb. \& Clin. Med., 49, 708, 1957.

2) Bennett, I.L. et al.: J.A.M.A., 183, 462, 1963.

3) Del Greco, F., Johnson, D.C.: J.A.M.A., 178, 994, 1961.

4) Forkner, C.E. et al.: Am. J. Med., 25, 877, 1958.

5) Gatch, W.D. et al.: J.A.M.A., 114, 1839, 1940.

6) Gilbert, R.P.: Rroc. Soc. Expe. Biol. \& Med., 100, 346, 1959.

7) Good, R.A., and Thomas, L.: J. Exp. Med., 97, 871, 1953.

8) Graber, C.D. et al.: Surg. Gynec. \& Obst., 110, 443, 1960.

9) Kinsell, L.K.: Ann. New York Acad. Sci., $63,240,1955$.

10) Lillehei, R.C., and Macleam, L.D.: Ann. Surg., 148, 513, 1@58.

11) Lillehei, R.C., and Maclean, L.D.: Arch. Surg., 78, 464, 1959.

12) Lillehei, R.C. et al.: Ann. Surg., 160, 682, 1964.

13) Maiztegui, J.I.. and Kass, E.H.: Am. J. Surg., 107, 701, 1964.

14) Margaretten, W., and McAdams, A.J.: Am. J. Med., 25, 868, 1958.

15) McCabe, W.R., and Jackson, G.G.: Arch, Int. Med., 110, 847, 1@63.

16) McKay, D.G. et al.: Am. J. Obst. Gynec., 78, 546, 1959.

17) Melby, J.C. et al.: J. Clin. Invest., 37,1791, 1958.

18) Review of medical microbiology., 14, 139, 
1964.

19）渋沢喜守雄 : ショック. 医学書院, 1959.

20) Shubin, H., and Weil, M.H.: J.A.M.A., 185, 850, 1963.

21) Spink, W.W., and Andreson, D.: J. Clin. Invest., 33, 540, 1954.

22) Spink, W.W.: New Engl. J. Med., 257, 1031, 1957.

23) Spink, W.W.: Ann. Int. Med., 53, 1, 1960.

24) Spink, W.W.: Arch. Int. Med., 106, 433, 1960.

25) Spink, W.W.: Shock. Academic Press, 1962.

26) Spink, W.W.: Ann. Int. Med., 57, 538, 1962.

27) Stetson, C.A.: J. Exp. Med., 94, 347, 1951.

28）住友健治：四国医誌，13，376，1958.

29) Talbot, C.H.: Lancet, 1, 668, 1962.

30) Thomas, L., and Good, R.A.: J. Exp. Med., 95, 409, 1952.
31) Thomas, L.: Arch. Int. Med., 101, 542, 1958.

32) 戸田忠雄 : 戸田新細菌学, 南山堂, 1964.

33) Udhoji, V.N. etal.: Am. J. Med., 34, 461, 1963.

34) Udhoji, V.N., and Weil, M.H.: Ann. Int. Med., 62, 966, 1965.

35) Weil, M.H., and Spink, W.W.: J Lab. \& Clin. Med., 501, 50, 1957.

36) Weil, M.H.: Circulation, 16, 1097, 1957.

37) Weil, M.H. et al.: Ann. Int. Med., 60, 384, 1964.

38) Weil, M.H., and Spink, W.W.: Arch. Int. Med., 101, 184, 1958.

39) Weisbren, B.A.: Am, J. Med., 36, 819, 1964.

40) Weisbren, B.A., and Arena, J.: Arch. Int. Med., 116, 336, 1965.

41) Zinsseer's Textbook of Bacteriology.

（昭和 42 年 2 月 25 日受付） 